\title{
Estratégias de intervenção policial no estado contemporâneo
}

a maior parte das sociedades do mundo ocidental, a violência constitui hoje uma das preocupações principais na agenda do cidadão comum. Atos de terrorismo, genocídios, perseguições políticas (muitas delas de origem étnica ou religiosa), enfim graves violações do mais elementar dos direitos humanos que é o direito à vida tendem a despertar a atenção da opinião pública.

Entre esses fatos, a violência criminal ocupa um espaço privilegiado. Pesquisas de opinião pública realizadas periodicamente nos Estados Unidos, Grã-Bretanha, Alemanha, países baixos, França, Itália têm indicado que o sentimento coletivo de medo e insegurança diante do crime tomou de assalto o cidadão comum, independentemente de suas diferenças de classe, de etnia, de gênero, de geração, de cultura ou qualquer outra clivagem social. Esse sentimento que se alastra comporta dupla percepção: não apenas a de que cresceram os crimes comparativamente ao passado recente, mas também a de que os crimes estão se tornando cada vez mais violentos.

Embora o crescimento do sentimento de insegurança seja fenômeno complexo e inseparável da construção da informação pelos meios de comunicação de massa, seria equivocado pensar que não há para ele qualquer fundamento (cf. Lagrange, 1995). A despeito de todas as advertências e ponderações de que se cercam os especialistas no emprego e manuseio de 
Para o caso da França, ver neste número artigo de René Lévy (p. 53-77).

2 Para o caso do Brasil, ver neste número o artigo de Jorge da Silva (p. 95-114).

3 Para o caso da França, ver neste número o artigo de Frédéric Ocqueteau (p.185195). estatísticas oficiais de criminalidade, estudos são unânimes em reconhecer fortes tendências ao aumento dos crimes contra o patrimônio, em especial àqueles que envolvem o recurso à violência, observáveis com maior ou menor intensidade na América e em praticamente toda a Europa ocidental. Ademais, e ainda que essa não seja uma tendência geral, elevaram-se nos Estados Unidos e Grã-Bretanha, desde meados dos anos 50 e de modo mais saliente a partir dos anos 60, as taxas de homicídios voluntários. Os estudos indicam igualmente a generalização do crime organizado, em bases empresariais e internacionais, sobretudo em torno do narcotráfico.

No contexto político atual, o Estado parece incapaz de velar pela segurança dos cidadãos e proteger-lhes os bens, materiais e simbólicos. As pesquisas de opinião pública revelam o sentimento de que os crimes não estão sendo punidos ou, quando o são, não o são com o rigor necessário. Estudos, em diferentes países, identificam a existência de crise no sistema de justiça criminal, manifesta em meados da década de 70 e cujos sinais mais agudos se revelam na atualidade. Taxas alarmantes de decréscimo das atividades policiais comparativamente ao aumento dos crimes estariam a indicar que a prevenção tem sido ineficaz ${ }^{1}$. Além disso, a ambigüidade do trabalho policial torna-se manifesta pelas regras que regem suas atividades. Por um lado, exigese dos policiais elevada produtividade, medida pela número de prisões efetuadas; por lado, pretende-se que eles cumpram essa exigência respeitando rigorosamente os ditames legais. Essa contradição engendra cultura organizacional que estimula verdadeira epidemia de práticas ilegais, cujos valores primordiais são o segredo e a solidariedade intra pares. Essas contradições vão igualmente espelhar-se em outras esferas das atividades policiais, como nos processos de seleção e de codificação de casos tratados, muitas vezes com critérios racistas (cf. Wieviorka, 1992) 2 e na própria dificuldade em definir e conceituar o trabalho policial, do ponto de vista de padrões éticos de conduta profissional.

Efeitos desse processo observam-se nas imagens e representações que cidadãos comuns revelam sobre as forças policiais, indicativas de graus de confiança, de expectativas e de mitos. O que os estudos vêm apontado com certa insistência é o declínio do consenso no apoio popular às operações policiais. Os policiais são percebidos como pessoas que aplicam a lei, de modo pouco satisfatório. A organização policial tornou-se uma organização complexa, afastada das comunidades locais, constrangida a recorrer prioritariamente à força mais do que ao consenso na contenção da ordem pública. Essa é uma das razões que explica o desenvolvimento, em ritmo acelerado, dos serviços de segurança privada (cf. Caldeira, 1992; Paixão, 1991) 3 às expensas do "monopólio da violência física legítima", antes revindicado pelo Estado moderno.

Em maior ou menor grau, diferentes sociedades do mundo ocidental vêm enfrentando a seu modo esse espectro de problemas. Ali onde prevalecem tradições democráticas, a crise afeta especialmente a confiança dos cidadãos 
nas instituições policiais, na sua capacidade em pacificar a sociedade e resolver conflitos nos estritos marcos do Estado democrático de Direito. Em sociedades de frágil tradição democrática, onde são fortes os traços herdados do patrimonialismo, esses desafios supõem tarefas complementares, entre as quais a de superar o perfil institucional autoritário das agências policiais. Problemas comuns também se colocam como o controle e repressão ao tráfico internacional de drogas e outras formas de crime organizado igualmente internacionalizadas.

O conjunto de artigos aqui apresentados constitui um esforço de reflexão sobre esses temas. Eles foram inicialmente debatidos no quadro do seminário internacional Estratégias de Intervenção Policial no Estado Contemporâneo, realizado no âmbito do Núcleo de Estudos da Violência da Universidade de São Paulo em setembro de 1996 e que contou com o apoio do Conselho Nacional de Desenvolvimento Científico e Tecnológico (CNPq), da Fundação de Amparo à Pesquisa do Estado de São Paulo (FAPESP) e da Comisão de Cooperação Internacional (CCInt), da USP. Lamentavelmente, nem todas as intervenção apresentadas no seminário puderam integrar este volume por diversas razões alheias à nossa vontade, porém todas elas justificáveis.

Concebido para reunir os principais especialistas sobre violência e estratégia policial no contexto político contemporâneo em sociedades do mundo ocidental, o seminário contou com a presença de dezessete pesquisadores associados a centros nacionais de excelência como o ISER (Instituto Superior de Estudos da Religião), Fundação Casa de Ruy Barbosa, Núcleo de Estudos sobre Sistema de Justiça Criminal da Universidade Federal Fluminense (UFF) e grupo de pesquisa sobre criminalidade e violência do Departamento de Sociologia da Universidade Federal do Rio Grande do Sul (UFRGS), bem como a centros internacionais como o Centre d'Analyse et d'Interventions Sociologiques (CADIS, França), o Centre de Recherches Sociologiques sur le Droit et les Institutions Pénales (CESDIP, França), o Groupe d'Analyse des Politiques Publiques (École Normale Supérieure, França) e o Núcleo de Estudos sobre Violência e Crime da Universidade de Toronto (Canadá). O seminário contou ainda com a presença de inúmeros representantes da polícia e da justiça paulistas cujo interesse e colaboração agradecemos.

A perspectiva internacional indica-nos quão árdua é, no atual momento, a tarefa de construção de uma polícia ao mesmo tempo eficiente e democrática, capaz de contribuir para uma redução das taxas de criminalidade, mas pautando seu desempenho na ordem legal, uma polícia que seja eficiente sem ser violenta ${ }^{4}$. Há desafios novos que, no caso brasileiro, se somam a desafios antigos. Procura-se avançar no sentido de equacioná-los. Os textos que se seguem são uma mostra disso.

Nosso desejo é que este debate se inscreva no legado de Antônio Luiz Paixão, que nos deixou precocemente poucos dias antes que o seminário se realizasse. A ele nossa homenagem.

Nossos agradecimentos a Mônica Lúcia Rique e Eduardo Manoel

\footnotetext{
${ }^{4}$ Quando acabávamos de redigir esta nota de apresentação, o Brasil inteiro foi surpreendido com as contundentes imagens da brutal violência cometida por dez policiais militares contra cidadãos na favela Naval, no município de Diadema, Estado de São Paulo, em 31/03/97.
} 
ADORNO, Sérgio \& PERALVA, Angelina. Nota de apresentação.Tempo Social; Rev. Sociol. USP, S. Paulo, 9(1): 1-4, maio de 1997.

de Brito cuja colaboração e dedicação foram imprescindíveis para que a edição dos textos fosse possível em tempo recorde. Agradecimentos também devemos ao editor de Tempo Social que não apenas acolheu com simpatia nossa proposta de publicação como também envidou todos os esforços para viabilizá-la.

abril/1997

CALDEIRA, Teresa (1992). City of walls: crime, segregation, and citizenship in São Paulo. Ph.D. Dissertation on Anthropology. Graduate Division of the University of California at Berkeley.

Lagrange, Hugues (1995). La civilité a l'épreuve. Crime et sentiment d'insécurité. Paris, PUF.

PaIxão, Antônio Luiz (1991). Segurança privada, direitos humanos e democracia. Novos Estudos CEBRAP. São Paulo, 31: 131-41.

WIEvioRKa, Michel. (1992). La France raciste. Paris, Éd. du Seuil. 